\title{
CREDIT RISK ASSESSMENT OF AGRICULTURAL ENTERPRISES IN THE REPUBLIC OF SERBIA: LOGISTIC REGRESSION VS DISCRIMINANT ANALYSIS
}

\author{
Dragana Tekićl, Beba Mutavdžićc , Dragan Milić3, Nebojša Novković, Vladislav Zekićs, \\ Tihomir Novaković ${ }^{6}$ \\ *Corresponding author E-mail: dragana.tekic@polj.uns.ac.rs
}

\begin{abstract}
A R T I C L E I N F O
A B S T R A C T

Original Article

Received: 17 January 2021

Accepted: 25 November 2021

doi:10.5937/ekoPolj2104881T

UDC 33.067:631.164.6(497.11)

Credit risk assessment of agricultural enterprises in the Republic of Serbia was analyzed in this research by applying discriminant analysis and logistic regressions. The aim of the research is to determine the financial indicators which financial analysts consider when analyzing a loan application that have the most influence on the decision to approve or reject a loan application. The internal determinants of credit

Keywords:

credit risk, financial risk, agricultural companies, logistic regression, discriminat analysis

JEL: G21, Q12 Q14

risk of agricultural enterprises are analyzed, i.e., indicators of financial leverage, profitability, liquidity, solvency, financial stability and effectiveness. The analyzed models gave different results in significance of the observed indicators. The indicators that stood out as significant in both models are only indicators of profitability and solvency. The model of discriminant analysis has successfully classified rate $81.0 \%$, while the logistic regression model has successfully classifies rate $89.8 \%$. In modeling the credit risk of agricultural enterprises in the Republic of Serbia, the logistic regression model gives better results.
\end{abstract}

(C) 2021 EA. All rights reserved.

1 Dragana Tekić, MAgrEC, Teaching Assistant, University of Novi Sad, Faculty of Agriculture, Trg D. Obradovića 8, 21000 Novi Sad, Serbia, Phone: +381 (21) 4853 380, E-mail: dragana. tekic@polj.uns.ac.rs, ORCID ID (https://orcid.org/0000-0002-1924-6196).

2 Beba Mutavdžić, PhD, Assistant Professor, University of Novi Sad, Faculty of Agriculture, Trg D. Obradovića 8, 21000 Novi Sad, Serbia, Phone: +381 (21) 4853 382, E-mail: beba. mutavdzic@polj.uns.ac.rs, ORCID ID (https://orcid.org/0000-0002-7631-0465).

3 Dragan Milić, PhD, Assistant Professor, University of Novi Sad, Faculty of Agriculture, Trg Dositeja Obradovića 8, 21000 Novi Sad, Serbia, Phone: +381 21 4853274, E-mail: dragan. milic@polj.edu.rs, ORCID ID (http://orcid.org/0000-0003-0377-1540).

4 Nebojša Novković, Ph.D., Full Professor, University of Novi Sad, Faculty of Agriculture, Trg D. Obradovica 8, Novi Sad, Serbia, Phone:+38162200132, E-mail: nesann@polj.uns. ac.rs, ORCID ID (https://orcid.org/0000-0003-2419-5765).

5 Vladislav Zekić, PhD, Full Professor, University of Novi Sad, Faculty of Agriculture, Trg Dositeja Obradovića 8, 21000 Novi Sad, Serbia, Phone: +381 21 4853510, E-mail: zekic@ polj.uns.ac.rs, ORCID ID (https://orcid.org/0000-0002-7377-2402).

6 Tihomir Novaković, Mmgt, Teaching Assistant, University of Novi Sad, Faculty of Agriculture, Trg Dositeja Obradovića 8, 21000 Novi Sad, Serbia, Phone: +381 21 4853307, E-mail: tihomir. novakovic@polj.uns.ac.rs, ORCID ID (http://orcid.org/0000-0002-8405-3403).

http://ea.bg.ac.rs 


\section{Introduction}

Many authors consider credit risk as one of the most important risks that can affect banks (Spasojević, 2013; Dragosavac, 2014). Credit risk is the risk that the client will fail to meet the obligations and terms of a contract. Credit risk is included in credit activities as well as in business and investment activities, payments and securities settlements (Sůvová, 2002). Many factors can affect credit risk, including those that are under the control of the bank and those that are beyond its control. Credit risk depends on two groups of factors: 1. exogenous (government regulations, general economic conditions, natural conditions, etc.); 2) endogenous (assessment of the creditworthiness of each client). There are various events generating credit risk and they can occur at any time in the life of a loan. Also, credit risk should be analyzed in terms of the clients' activity sector, taking into consideration the particularities of each client's business (Sbârcea, 2008). Agriculture is the activity sector with the highest risk, primarily due to characteristics of agricultural production including: dependence on climatic conditions, slow turnover of funds, specific method of reproduction, lower level of marketability, seasonal nature of work, etc. When modeling credit risk for agricultural loans, one must take into account the characteristics of both the agricultural sector and its borrowers. Performance of the sector is influenced also by economic cycles and it is highly correlated with the typology, commodity, and geographical location of the company (Bandyopadhyay, 2007). Agricultural production in the Republic of Serbia is of great importance, the share of agricultural production in total GDP is about $6 \%$ (World Bank, 2019). Consequently, the performance of agricultural enterprises in the Republic of Serbia is one of the crucial aspects of the national economy. The main information on agricultural enterprises is given in their financial statements. These reports provide a view of the financial position and business results for the observed period (Milić et al., 2018). Therefore, the paper analyzes the financial ratios considered by financial analysts when making a decision to accept or reject a loan application from agricultural companies. Researches related to the topic of credit risk of agricultural enterprises are rare. Given that Wen (2013) considers that nonperforming loans makes a negative result of the bank's credit risk, the author investigated the impact of indicators such as gross domestic product, interest rate and money supply on the ratio of nonperforming loans of the Agricultural Bank of China. The results of this study determined that all three observed factors have a significant joint impact on nonperforming loans. Shalini (2013) in a survey of farmers in India identified the impact of a number of microeconomic variables on agricultural credit management. This research also proposes measures that can minimize the number of nonperforming loans in India. In their research, Khanam and Hasan (2013) examined the factors influencing nonperforming loans from the agricultural sector, a bank in Bangladesh. The authors came to the conclusion that a high percentage of nonperforming loans reduces the productivity and profitability of banks. Muhović et al. (2019) investigated the impact of various indicators on the movement of nomperforming loans in three countries: Republic of Serbia, Bosnia and Herzegovina and Montenegro. Using the panel analysis authors came to the conclusion that both, microeconomic and macroeconomic factors stand out as significant. 
Finding an appropriate model for credit risk assessment is becoming an increasingly important issue for the banking system of the Republic of Serbia, therefore the aim of this research is to demonstrate how a discriminant analysis and binary logistic regression models can be used for this purpose. In this paper we analyze credit risk assessment by using financial dataset consisting of 295 loan applications of one bank located in Serbia. The research started from the hypothesis that used models, discriminant analysis and binary logistic regression can be used to model the credit risk of the observed companies.

\section{Material and methods}

The selected indicators which are considered by financial analysts when making a decision of accepting or rejecting a credit loan application were analyzed by applying two statistical methods: discriminant analysis and binary logistic regression. These methods can be used to estimate the associations between a categorical outcome variable and various covariates. Logistic regression and discriminant analysis are widely implemented practically (Ahsan ul Haq et al., 2015). Logistic regression, unlike discriminant analysis, is not based on assumptions about data normality and correlation of independent variables.

\section{Discriminant analysis}

The method of discriminant analysis is a multivariate technique for analyzing differences between individual groups of features. Discriminant analysis determines which variables better explain or predict affiliation of observations to certain groups (Tillmanns\&Krafft, 2017). It is used to determine the discriminant function and to classify objects into one or two or more groups based on a set of characteristics that describe the objects. The goal is to maximize the difference between two groups and minimize the differences between individual members of the same group (Gurný P. \&Gurný M., 2013).

The discriminant function is a linear combination of discriminant variables (Hair et al., 2006):

$Z_{j k}=a+W_{1} X_{1 k}+W_{2} X_{2 k}+\ldots+W_{n} X_{n k}[1]$

$Z_{j k}=$ discriminant $\mathrm{Z}$ score of the discriminant function $\mathrm{j}$ for object $\mathrm{k}$

$\mathrm{a}=$ intercept

$W_{i=1,2 . . n}=$ discriminant weight for independet variable $\mathrm{i}$

$X_{i k}=$ independet variable $\mathrm{i}$ for object $\mathrm{k}$

Discriminant analysis is based on the following assumptions: 1) equality of variances and covariances of independently variables; 2) independently variables follow multivariate normal distribution; 3) independence (Ahsan ul Haq et al., 2015; Brusco et al., 2018). Kolmogorov-Smirnov test was applied for testing the normality of data. 
Homoscedasticity is tested using Leven test and Brown-Forsythe group test. Box's M statistic was used for testing homogeneity of the group covariance matrices.

The test used to interpret the discriminant functions is Wilk's $\lambda$-test, which is a measure of the differences among group means of the explanatory variables, and it was used to ascertain the level of significance for each group prediction (Heil \&Schmidhalter, 2014). The classification function coefficient analysis shows more about the importance of each indicator in the discriminant function.

\section{Logistic regression}

Logistic regression is a statistical technique for modeling categorical variables which is generally most widely used in biomedical research, but it is also increasingly used in areas such as business and finance, marketing and economics (Meyers, et al., 2006). Logistic regression is a special type of regression used to predict the outcome of binary variables, i.e., magnitudes that can have two possible outcomes (e.g., success / failure). The dependent variable in the binary logistic regression model must be dichotomous (Hosmer et al., 2013).

The model of logistic regression has a following form:

$\pi(x)=\frac{e^{\alpha+\beta 1 X 1+\beta 2 X 2+\cdots+\beta k X k}}{1+e^{\alpha+\beta 1 X 1+\beta 2 X 2+\cdots+\beta k X k}}[2]$

$\pi(x)=\frac{e^{\alpha+\beta_{1} x_{1}+\beta_{2} X_{2}+\cdots+\beta_{k x k}}}{1+e^{\alpha+\beta_{1} x_{1}+\beta_{2} x_{2}+\cdots+\beta k \times k}}[2]$ Where $\pi(x)$ is the expected value of $Y$ for a given value of $X$, while the $\alpha$ and $\beta 1,2 \ldots \mathrm{k}$ corresponds to the parameters $\alpha$ and $\beta 1,2 \ldots \mathrm{k}$ from the linear regression model (Tekić et al., 2020). This function is nonlinear and in order to linearize it is necessary to perform an appropriate transformation.

If the logistic regression function is transformed, the function is following: (Kvesić, 2012):

$\ln \left(\frac{\pi}{1-\pi}\right)=\alpha+\beta 1 \mathrm{x} 1+\beta 2 \mathrm{x} 2+\cdots \beta \mathrm{kxk}[3]$

The resulting equality is called logit and it is linear with the parameters $\beta \mathrm{i}, \mathrm{i}=1 \ldots \mathrm{k}$. The method commonly applied for testing the parameters in the logistic regression model is the maximum likelihood estimator, while Wald statistic test is used to estimate the significance of coefficients (Basu et al., 2017).

The Hosmer-Lemeshow test was used to assess the suitability of the data to the model (Hosmer et al., 2013). The tool used to assess the predictive accuracy of the model is the classifications matrix. The applied methods included calculation of Cox \& Snell and Nagelkerke pseudo- $\mathrm{R}^{2}$ coefficients. These coefficients have the maximum value of 1 and the closer the value is to 1 , the more accurate the model is (Walker \& Smith, 2016). 


\section{Sample and used variables}

The statistical analysis included 295 loan applications made by agricultural companies taken from a bank operating in the Republic of Serbia. These loan applications of agricultural companies were processed by the bank in the period 2017-2019. Software packages used for statistical data processing were SPSS 21 and R 3.6.3. As a dependent variable in this analysis, a dichotomous variable was observed: credit application approved (yes or no). A set of financial and accounting ratios, belonging to different categories such as liquidity, solvency, profitability and economic structure, were selected from the accounts of these agricultural companies as independent variables:

Table 1. Independent variables

\begin{tabular}{|l|l|l|}
\hline Notation & \multicolumn{1}{|c|}{ Indicator } & \multicolumn{1}{c|}{ Explanation } \\
\hline LEV & Leverage & Total liabilities/total equity \\
\hline NIIE & Interest ratio & Net income/ interest expenses \\
\hline NIOI & Ratio of net income and operating income & Net income/operating income \\
\hline ROA & Return on assets & Net income / total assets \\
\hline ROE & Return on equity & Net income / total equity \\
\hline LIQ & Liquidity & Current assets/ short-term liabilities \\
\hline FLTA & Ratio of financial liabilities and total assets & Financial liabilities/ total assets \\
\hline STB & Stability & $\begin{array}{l}\text { Fixed assets-long-term liabilities/total } \\
\text { assets }\end{array}$ \\
\hline SOL & Solvency & Total equity/ total assets \\
\hline EFF & Total cost-effectiveness & Total income / total expenses \\
\hline
\end{tabular}

Source: authors' review

The leverage indicator (LEV) indicates the degree of capital burden on total liabilities. In essence, the rule is that the lower the value of this ratio, the greater are the security of long-term creditors and the solvency of the company. Interest ratio (NIIE) measures how much space there is between interest costs and company earnings. The larger the space, the safer the claims of long-term creditors will be and vice versa.Net income and operating income ratio (NIOI): operating profit shows the company's earnings after all expenses have been removed, except for tax expenses and certain one-off items, on the other hand, net profit shows the profit that remains after all operating expenses incurred in that period have been deducted from sales revenue. Return on assets (ROA) and Return on Equity (ROE) are indicators of company`s profitability which are the most used in the analysis (Walsh, 2003). Liquidity (LIQ) is the ability of a company to meet its obligations as they fall due. It can be measured in several ways, we used quick ratio which analyzes current assets and short-term liabilities. Ratio of financial liabilities and total assets (FLTA) shows the degree of indebtedness of companies to banks. Ratio of financial stability (STB), this coefficient indicates how many long-term sources, which consist of capital and fixed liabilities, related to fixed assets. Indirectly this indicator indicates the size of working capital, which is important preservation factor liquidity, because it represents reserve liquidity. The fixed assets coverage ratio (SOL) shows the extent to which fixed assets are financed by equity. The limit value of this indicator is 1 . 
If the value of the ratio is above one, the company is considered to be solvent. The ratio of total cost-effectiveness of the enterprise (EFF) is obtained when total revenues and total expenditures are compared. When this ratio was less than 1 , the company realized a lower amount of income from expenses and then cost-effectiveness is unsatisfactory.

\section{Results and Discussions}

Out of 295 observed loan applications, 207 applications were accepted, while 88 loan applications were rejected. A list of the independently variables analyzed during the loan application processing and descriptive statistics of intependently variables are presented in Table 2.

Table 2. Descriptive statistics of explanatory variables

\begin{tabular}{|l|r|r|r|r|}
\hline \multicolumn{1}{|c|}{ Indicator } & \multicolumn{2}{c|}{ Mean } & \multicolumn{1}{c|}{ Minimum } & \multicolumn{1}{c|}{ Maximum } \\
\hline LEV & 2.79 & 0.00 & 330.67 & Std. Deviation \\
\hline NIIE & $3,547,573.33$ & $710,210,000.00$ & $741,030,000.00$ & $87,575,655.17$ \\
\hline NIOI & 1.24 & $-4,280.86$ & 456.49 & 364.59 \\
\hline ROA (\%) & -7.38 & -90.68 & 61.67 & 10.69 \\
\hline ROE (\%) & 2.72 & $-2,486.36$ & 864.11 & 154.76 \\
\hline LIQ & 6.88 & 0.03 & 689.79 & 42.67 \\
\hline FLTA & 0.11 & 0.00 & 0.77 & 0.14 \\
\hline STB & 0.41 & -0.48 & 0.99 & 0.29 \\
\hline SOL & 0.59 & 0.00 & 0.99 & 0.26 \\
\hline EFF & 0.79 & 0.03 & 2.27 & 0.25 \\
\hline
\end{tabular}

Source: authors' calculation

From the results shown in Table 2, it can be seen that the average indebtedness of the analyzed companies is 2.79 , and it ranged from 0 to 330.67. The high average value of the debt ratio is a consequence of the high indebtedness of those companies in the sample that were not approved for loan applications. The same can be concluded for the other observed indicators, especially the indicators of profitability and effectiveness (ROA and ROE and EFF), whose average values are extremely low, due to the low profitability of the rejected companies in the sample. The liquidity of the observed companies was at a satisfactory level, the average observed value of the current liquidity ratio was above 2 , which means that the ratio of current assets and short-term liabilities is higher than the recommended ratio of $2: 1$. The solvency of the observed companies is also endangered, the minimum value of the solvency ratio is 0 , while the maximum is 0.99 .

The analysis was started by testing the collinearity of the variables; a correlation matrix is used within the groups to show correlation between the variables (Table 3 ). From the results shown in Table 3 it can be seen that the highest correlation coefficients are determined between NIIE and ROE $(r=-0.88)$, followed by NIOI and ROA $(r=0.56)$ and STB and SOL $(r=0.56)$. 
Table 3. Correlation matrix

\begin{tabular}{|c|c|c|c|c|c|c|c|c|c|c|}
\hline Indicator & LEV & NIIE & NIOI & ROA & ROE & LIQ & FLTA & STB & SOL & EFF \\
\hline LEV & 1.00 & $-0.28^{* *}$ & 0.01 & -0.04 & $-0.88^{* *}$ & -0.02 & $0.24^{* *}$ & 0.01 & $-0.24^{* *}$ & -0.05 \\
\hline NIIE & & 1.00 & $0.12^{*}$ & $0.17^{* *}$ & $0.31^{* *}$ & 0.02 & -0.07 & -0.02 & 0.09 & $0.15^{* *}$ \\
\hline NIOI & & & 1.00 & $0.56^{* *}$ & 0.08 & 0.02 & -0.05 & 0.01 & 0.07 & $0.43^{* *}$ \\
\hline ROA & & & & 1.00 & $0.26^{* *}$ & 0.01 & 0.08 & -0.12 & -0.01 & $0.56^{* *}$ \\
\hline ROE & & & & & 1.00 & 0.01 & $-0.15^{*}$ & -0.10 & 0.08 & $0.16^{* *}$ \\
\hline LIQ & & & & & & 1.00 & -0.09 & -0.01 & $0.18^{* *}$ & -0.07 \\
\hline FLTA & & & & & & & 1.00 & $-0.20^{* *}$ & $-0.50^{* *}$ & 0.08 \\
\hline STB & & & & & & & & 1.00 & $0.56^{* *}$ & $-0.34^{* *}$ \\
\hline SOL & & & & & & & & & 1.00 & $-0.23^{* *}$ \\
\hline EFF & & & & & & & & & & 1.00 \\
\hline
\end{tabular}

Source: authors' calculation

**Corerelation is significant at the 0.01 level

*Correlation is significant at the 0.05 level

Levene's test is performed to test the assumption of homogeneity of variance for individual variables between groups. Brown-Forsythe test, which is based on Levene's test, is performed to test equity of group means (Table 4).

Table 4. Results of Levene's and Brown-Forsythe tests

\begin{tabular}{|l|r|r|r|r|}
\hline \multicolumn{1}{|c|}{ Indicator } & \multicolumn{1}{c|}{ Levene's statistics } & \multicolumn{1}{c|}{ Sig. } & \multicolumn{1}{c|}{ Brown-Forsythe statistics } & \multicolumn{1}{c|}{ Sig. } \\
\hline LEV & 8.724 & 0.003 & 1.966 & 0.164 \\
\hline NIIE & 2.510 & 0.114 & 9.883 & 0.002 \\
\hline NIOI & 39.602 & 0.001 & 6.796 & 0.011 \\
\hline ROA & 25.131 & 0.001 & 28.339 & 0.001 \\
\hline ROE & 9.590 & 0.002 & 1.340 & 0.250 \\
\hline LIQ & 4.148 & 0.043 & 4.372 & 0.038 \\
\hline FLTA & 14.875 & 0.001 & 10.797 & 0.001 \\
\hline STB & 8.818 & 0.003 & 0.004 & 0.947 \\
\hline SOL & 6.813 & 0.010 & 37.078 & 0.001 \\
\hline EFF & 11.117 & 0.001 & 19.354 & 0.001 \\
\hline
\end{tabular}

Source: authors' calculation

The results of Levene's test for all variables indicate that the variances are not homogenous. The results of Brown-Forsythe test show statistically significant group mean. Box's M test was used to test the existence of group covariance matrices homogeneity. The value of Box's M statistics is 4,016.011 with p-value $<0.005$, so it can be concluded that the groups' covariance matrices are unequal.

One of the assumptions of discriminant analysis refers to normality of the original data. Kolmogorov-Smirnov test statistic is applied for this purpose and all variables show deviations from the normal distribution. Based on the performed tests, it is noticed that no agreement was reached with the normal distribution, so the Box Cox transformation was performed. 


\section{Results of discriminant analysis}

Based on the results shown in Table 5, it can be seen that only one canonical function was isolated.

Table 5. Results of discriminant function

\begin{tabular}{|r|r|r|r|r|r|}
\hline Function & Eigenvalue & $\begin{array}{c}\text { Canonical } \\
\text { correlation }\end{array}$ & Wilks' lambda & Chi-square & \multicolumn{1}{c|}{ Sig. } \\
\hline 1 & 0.574 & 0.604 & 0.635 & 130.441 & 0.001 \\
\hline
\end{tabular}

Source: authors' calculation

Eigen values are related to the canonical correlation and describe the power of discrimination function. The correlation is 0.604 . Wilk's lambda tests how well two levels of independent variable contribute to the model and the significance of discriminant function. Confirmed results, Wilks' lambda $=0.635$ and $\chi 2=130.441$, correlation coefficient and eigenvalue indicate the significance of the function (Table 5).

In Table 6, explanatory variables are sorted according to the importance of separation.

Table 6. Structure matrix

\begin{tabular}{|l|r|}
\hline \multicolumn{1}{|c|}{ Indicator } & \multicolumn{1}{c|}{ Function } \\
\hline ROA & 0.555 \\
\hline SOL & 0.509 \\
\hline EFF & 0.365 \\
\hline NIOI & 0.307 \\
\hline FLTA & -0.295 \\
\hline NIIE & 0.265 \\
\hline LEV & -0.161 \\
\hline ROE & 0.137 \\
\hline LIQ & 0.105 \\
\hline STB & -0.005 \\
\hline
\end{tabular}

Source: authors' calculation

The largest correlation with discriminant function is made by the variable ROA $(0.555)$, followed by SOL (0.509). The variable STB (-0.005) has the smallest contribution and the smallest correlation. It can be, also, noticed that all coefficients are statistically significant.

Table 7. Coefficients

\begin{tabular}{|l|r|r|}
\hline \multicolumn{1}{|c|}{ Indicator } & Standardized coefficients & \multicolumn{1}{c|}{ Discriminant function coefficients } \\
\hline LEV & -0.402 & -0.405 \\
\hline NIIE & 0.201 & 0.205 \\
\hline NIOI & -0.147 & -0.150 \\
\hline ROA & 0.730 & 0.790 \\
\hline ROE & -0.578 & -0.580 \\
\hline LIQ & -0.005 & -0.005 \\
\hline FLTA & -0.105 & -0.107 \\
\hline
\end{tabular}




\begin{tabular}{|l|r|r|}
\hline \multicolumn{1}{|c|}{ Indicator } & Standardized coefficients & \multicolumn{1}{c|}{ Discriminant function coefficients } \\
\hline STB & -0.370 & -0.369 \\
\hline SOL & 0.851 & 0.911 \\
\hline EFF & 0.300 & 0.311 \\
\hline Constant & & 0.001 \\
\hline
\end{tabular}

Source: authors' calculation

Standardized canonical coefficients of the discriminant function (Table 7) represent a relative measure of the influence of each explanatory variable on the discriminant function. The explanatory variable showing the greatest discriminatory influence is SOL, second is ROA, then ROE, and the other explanatory variables have less influence. The most significant explanatory variables have a positive sign of the coefficient of discriminatory function, which means that with increasing profitability and solvency of the company increases the probability that the loan will be approved.

Based on the results from Table 7, the equation of isolated function is:

$$
\begin{array}{r}
Z=0.001-0.405 T L T E+0.025 \text { NIIE }-0.150 \mathrm{NIOI}+0.790 \mathrm{ROA}-0.580 \mathrm{ROE} \\
-0.005 \mathrm{LIQ}-0.107 \mathrm{FLTA}-0.369 \mathrm{STB}+0.911 \mathrm{SOL}+0.311 \mathrm{EFF}
\end{array}
$$

\section{Results of logistic regression}

The backward stepwise method is used to construct the regression model. The selection of variables is conducted in five steps. Only the results of the fifth step, final model, will be presented. Omnibus test, i.e., "goodness of fit" is applied to assess the predictive performance of the chosen model.

\begin{tabular}{|c|c|c|c|}
\hline Step & Chi-square & df & Sig. \\
\hline \multirow[t]{2}{*}{ Step 5} & -1.706 & 1 & 0.191 \\
\hline & 220.561 & 7 & 0.001 \\
\hline
\end{tabular}

Table 8. Goodness of fit

Source: authors' calculation

Goodness of fit test (Table 8) show that the chosen model has good predictive performance and differs statistically significantly from the initial model without independently variables (Sig. $<0.05$ ). Based on the results of the Hosmer-Lemeshow test, the same conclusion is reached.

Table 9. Hosmer and Lemeshow test results

\begin{tabular}{|l|r|r|r|}
\hline \multicolumn{1}{|c|}{ Step } & \multicolumn{1}{|c|}{ Chi-square } & Df & \multicolumn{1}{c|}{ Sig. } \\
\hline 5 & 7.625 & & 8 \\
\hline
\end{tabular}

Source: authors' calculation

Based on the results of the Hosmer-Lemeshow test, it can be seen that the model is good for prediction (Sig. $>0,05$ ). 
Both Cox \& Snell R Square and Nagelkerke R Square coefficients are calculated to estimate the fit of the model to the data.

Table 10. Model summary

\begin{tabular}{|l|r|r|r|}
\hline Step & \multicolumn{1}{|c|}{ Log likelihood } & Cox \& Snell R Square & Nagelkerke R Square \\
\hline 5 & 138.997 & 0.527 & 0.747 \\
\hline
\end{tabular}

Source: authors' calculation

In the Table 10, the values of pseudo coefficients are presented. Nagelkerke's $\mathrm{R}^{2}=0.747$ shows how well a linear model fits the data, indicating a strong relationship. Cox \& Snell $\mathrm{R}^{2}=0.527$ indicating that $52.7 \%$ of the variation of the dependent variable is explained by explanatory variables from the logistic model.

Table 11 presents information about the variables included in the final model (equation). Based on the results of the Wald test, the contribution of each independent variable is determined.

Table 11. Variables in the equation

\begin{tabular}{|c|l|r|r|r|r|r|r|}
\hline Step & Variables & \multicolumn{1}{c|}{ B } & \multicolumn{1}{c|}{ S.E. } & \multicolumn{1}{c|}{ Wald } & \multicolumn{1}{c|}{ df } & \multicolumn{1}{c|}{ Sig. } & \multicolumn{1}{c|}{ Exp(B) } \\
\hline \multirow{5}{*}{ Step 5 } & LEV & 0.112 & 0.040 & 7.759 & 1 & 0.005 & 1.118 \\
\cline { 2 - 8 } & NIIE & 0.001 & 0.001 & 6.547 & 1 & 0.011 & 1.000 \\
\cline { 2 - 8 } & NIOI & 0.279 & 0.088 & 10.077 & 1 & 0.002 & 1.322 \\
\cline { 2 - 8 } & ROA & 0.352 & 0.167 & 4.422 & 1 & 0.035 & 1.422 \\
\cline { 2 - 8 } & ROE & -0.117 & 0.046 & 6.340 & 1 & 0.012 & 0.890 \\
\cline { 2 - 8 } & STB & -3.625 & 1.223 & 8.783 & 1 & 0.003 & 0.027 \\
\cline { 2 - 8 } & SOL & 9.216 & 1.646 & 31.352 & 1 & 0.001 & $10,055.766$ \\
\cline { 2 - 8 } & Constant & -2.788 & 0.612 & 20.752 & 1 & 0.001 & 0.062 \\
\hline
\end{tabular}

Source: authors' calculation

From the results shown in Table 10 it can be seen that seven out of eleven independently variables are statistically significant. In the final model, the main indicators of influence are LEV $(\mathrm{Sig}=0.005)$, NIIE (Sig = 0.011), NIOI $(\mathrm{Sig}=0.002)$, ROA $(\mathrm{Sig}=0.035)$, ROE $(\mathrm{Sig}=0.012), \operatorname{STB}(\mathrm{Sig}=0.003)$ and SOL $(\mathrm{Sig}=0.001)$, while other four factors are not statistically significant predictors. All explained variables except ROE and STB have a positive sign of the regression coefficient, which means that with the increase of TLTE, NIIE, ROA and SOL it is expected that the loan application will be approved.

Based on the coefficients B of the independently variables in the model, its equation is:

$$
\begin{gathered}
Y=-2.788+0.112 \mathrm{TLTE}+0.001 N I I E+0.279 N I O I+0.352 R O A-0.117 R O E \\
-3.625 S T B+9.216 S O L
\end{gathered}
$$




\section{Discriminant analysis vs. logistic regression}

The Receiver Operator Characteristic (ROC) is measure for assessing logistic regression and classification performance of discriminant analysis model (Hosmer et al. 2013). The ROC curve is presented in Figure 1.

Figure 1. ROC curve

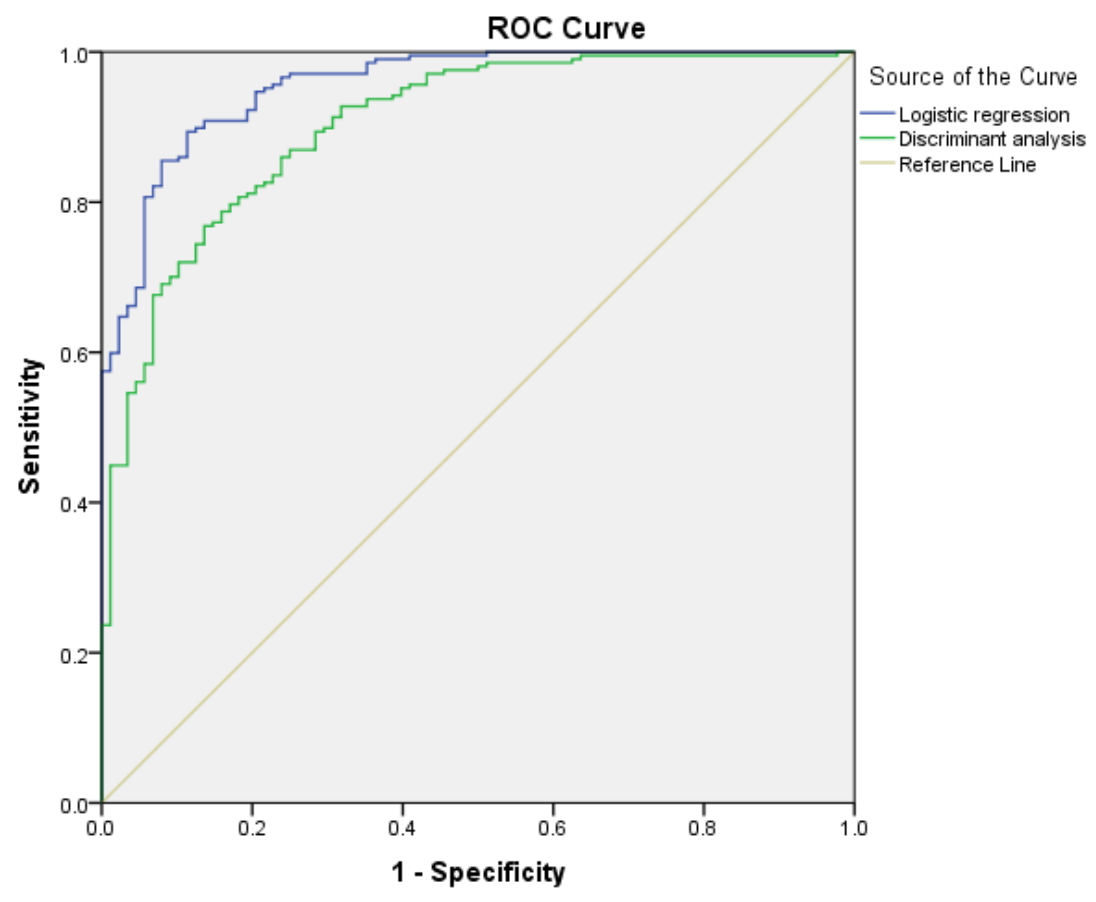

Source: authors' calculation

For the purpose of additional analysis of the predictive power of the two applied statistical methods, the area under rock curve (AUC) was calculated. If AUC has a value less than 0.5 , the model has no predictive power.

Table 12. Area under the curve

\begin{tabular}{|l|r|r|r|r|r|}
\hline \multirow{2}{*}{ Method } & \multicolumn{1}{|l|}{ Area } & \multicolumn{1}{l|}{ Std. Error } & Asymptotic Sig. & \multicolumn{2}{|l|}{$\begin{array}{l}\text { Asymptotic 95\% confidence } \\
\text { interval }\end{array}$} \\
\hline Discriminant analysis & 0.902 & 0.019 & 0.000 & 0.866 & 0.939 \\
\hline Logistic regression & 0.956 & 0.011 & 0.000 & 0.933 & 0.978 \\
\hline
\end{tabular}

Source: authors' calculation

Based on the results shown in Table 12, it can be seen that the logistic regression has AUC of 0.956 , while discriminant analysis has AUC of 0.902 . The areas of both analyses show outstanding discrimination. 
Table 14 presents the classification results of both statistical methods. The results of classification show how precisely the selected model predicts the categories of dependent variables. From the results of the classification, it can be seen that the model of discriminant analysis has successfully classification rate of $81.0 \%$, while the model of logistic regression has successfully classification rate of $89.8 \%$.

Table 13. Classification table

\begin{tabular}{|l|l|l|l|l|r|}
\hline Loan application & \multicolumn{6}{|l|}{ Discriminant analysis } & \multicolumn{2}{l|}{ Logistic regression } \\
\hline & Rejected & Accepted & Rejected & Accepted \\
\hline Rejected & 69 & 19 & 69 & 19 \\
\hline Accepted & 37 & 170 & & 11 & 196 \\
\hline Total (\%) & & 81.0 & & & 89.8 \\
\hline
\end{tabular}

Source: authors' calculation

In the next step of the analysis, the sensitivity and specificity of both models were calculated (Table 13).

Table 14. Comparison of models

\begin{tabular}{|c|c|c|l|r|r|}
\hline \multicolumn{2}{|l|}{ Discriminant analysis } & \multicolumn{4}{l|}{ Logistic regression } \\
\hline Sensitivity (\%) & Specificity (\%) & AUC (\%) & Sensitivity (\%) & Specificity (\%) & AUC (\%) \\
\hline 89.95 & 65.09 & 90.2 & 91.16 & 86.25 & 95.6 \\
\hline
\end{tabular}

Source: authors' calculation

Based on results (from Table 14) it can be seen that logistic regression has higher sensitivity and specificity power than discriminant analysis. Also, based on the AUC values, it can be noticed that the logistic regression model is better than discriminant analysis model.

\section{Conclusions}

Credit risk modeling is a serious challenge in all branches of business, and certainly the biggest challenge is to model and predict credit risk in agriculture. In this paper we compared two statistical techniques: discriminant analysis and binary logistic regression to determine the influence of eleven ratio indicators on the likelihood that a credit loan application will be accepted. Based on the results of discriminant analysis, the most important ratio indicators influencing the approval of a loan application are total equity to total assets ratio, return on assets and return on equity (profitability indicators). Wilks' lambda test and the canonical correlation coefficient value shown the significance of isolated function. The results of binary logistic regression indicated that the most important predictors included: leverage ratio, net income to interest expense ratio, net income to operating income ratio, profitability ratios (ROA and ROE), stability ratio and total cost-effectiveness. Significance of logistic regression mode was confirmed by Omnibus test, Hosmer-Lemeshow test and Pseudo R Square coefficients. Both models show that solvency and profitability indicators stand out as significant determinants of credit risk of the observed agricultural enterprises. The comparison of 
models was performed by using the overall classification rate, sensitivity, specificity and area under the ROC curve (AUC). The results showed that the logistic regression model exceeds the discriminant analysis model in all observed parameters. Based on all the above, it can be concluded that both statistical models can be successfully applied in financial institutions when modeling credit risk, but that for analyzed enterprises from the Republic of Serbia, the logistic regression model is a better basis for prediction.

It is important to note that the research was conducted on a sample of only 295 agricultural companies, for the period of the last three years, so in the future researches, the sample size should be increased.

\section{Conflict of interests}

The authors declare no conflict of interest.

\section{References}

1. Ahsan Ul Haq, M., Irum Sajjad, D. \&Qura-Tul-Ain. (2015). Performance comparison of classification techniques, artifical neural network, discriminant analysis \& logistic regression. Science International, 27 (3),1803-1807.

2. Bandyopadhyay, A. (2017). Credit Risk Models for Managing Bank's Agricultural Loan Portfolio. National Institute of Bank Management, Pune, India.

3. Basu, A., Ghosh, A., Mandal, A., Mart'In, N. \& Pardo, L. A. (2017). Wald-type test statistic for testing linear hypothesis in logistic regression models based on minimum density power divergence estimator. Electronic Journal of Statistics, 11 (2),2741-2772. doi: 10.1214/17-EJS1295

4. Brusco, J. M., Voorhees, M. C., Calantone, J. R., Brady, K. M. \& Steinley, D. (2018). Integrating linear discriminant analysis, polynomial basis expansion and genetic search for two-group classification. Communications in Statistics-Simulation and Computation, 48 (6), 1623-1636. doi: 10.1080/03610918.2017.1419262

5. Dragosavac, M. (2014). Teorijski concept upravljanja kreditnim rizikom. Škola biznisa. Visoka poslovna škola strukovnih studija Novi Sad, 1,108-116. [in English: Dragosavac, M. (2014). Theoretical concept of credit risk management, School of business, 1, 108-116.] doi: 10.5937/skolbiz1-5797

6. Gurný, P. \& Gurný, M. (2013). Comparison of credit scoring models on probability of default estimation for Us banks. Prague economic papers, 22 (2), 163-181. doi: $10.18267 /$ j.pep.446

7. Hair, J., Black, W., Babin, B., Anderson, R. \& Tatham, R. (2006). Multivariate data analysis, Pearson Prentice Hall, New Jersey.

8. Heil, K. \&Schmidhalter, U. (2014). Using discriminant analysis and logistic regression in mapping quaternary sediments. Math Geosci, 46 (3), 361-376. doi: 10.1007/s11004-013-9486-X

9. Hosmer, W. D., Lemeshow, S. \&Stradivant, X. R. (2013). Applied Logistic Regression, Third Edition, John Wiley \& Sons, Inc., Hoboken, New Jersey. 
10. Khanam, A. F. \& Hasan, K. (2013). Evaluation of Management of Agricultural Credit-A Case Study on Bangladesh Krishi Bank. Journal of Education and Practice, 4(13), 31-36.

11. Kvesić, Lj. (2012). Statistical methods in credit risk management. Review of Contemporary Entrepreneurship, Business, and Economic Issues, 25 (2), 319-324.

12. Meyers, L., G. Gamst, G. \& Guarino, A. (2006). Applied multivariate research: design and interpretation. Newbury Park, CA: Sage publications, London.

13. Menard, S. (2002). Applied logistic regression analysis (2nd ed.). Thousand Oaks: Sage.

14. Milić, D., Mijić, K., Jakšić D. (2018). Opportunistic management behavior in reporting earnings of agricultural companies. Custos e @gronegocio on line, 14 (1), $125-142$.

15. Muhović, A., Radivojević, N. \& Ćurčić, N. (2019). Research of factors of non performing agricultural loans by primary data panels. Economics of Agriculture, 66 (2),569-578. doi: 10.5937/ekoPolj1902569M

16. Shalini, H. S. (2013). A study on causes and remedies for non-performing assets in Indian public sector banks with special reference to agricultural development branch, state bank. International Journal of Scientific Research and Review, 8 (2), 26-38.

17. Sbârcea, I. (2008). Management of credit riskis in agriculture. Studies in Business and Economics, Lucian Blaga University of Sibiu, Faculty of Economic Sciences, 3 (3), 70-73.

18. Sůvová, H. (2002) The bank approach to a credit obligor - a farm business - in the context of credit risk and capital adequacy. Agric. Econ. - Czech, 48,395-398.

19. Spasojević, J. (2012). Credit risk and credit derivatives. Bankarstvo, 1, 104-137.

20. Tekić, D., Mutavdžić, B., Novaković, T. \&Pokuševski, M. (2020). Analysis of development of local self-government units in Vojvodina. Economics of Agriculture, 67 (2),431-443. doi: 10.5937/ekoPolj2002431T

21. Tillmanns, S. \& Manfred, Krafft. (2017) Handbook of Market Research. Springer International Publishing AG 2017, C. Homburg et al. (eds).

22. Walker, D. \& Smith, T. Jmasm. (2016) Algorithms and code nine pseudo R indices for binary logistic regression models. Journal of Modern Applied Statistical Methods, 15 (1), 848-854.

23. Walsh, C. (2003). Key Management Ratios. Prentice Hall, London, United Kingdom.

24. Wen, Z. Y. (2015). The analysis of the influence of gdp, lir and $m \mathrm{~m} 2$ towards nonperforming loans ratios (case study in agricultural bank of China in 2009 - 2013). Faculty of Business President University. 